\title{
Effects of Ascorbic Acid, Dehydroascorbic Acid and Methotrexate on Breast Cancer Cell Viability
}

\author{
Yewande Dosunmu $^{1}$ and Richard Owusu-Apenten ${ }^{1^{*}}$ \\ ${ }^{1}$ Biomedical Sciences Research Institute, University of Ulster, Coleraine, BT52 1SA, United Kingdom.
}

Authors' contributions

This work was carried out in collaboration between both authors. Author ROA designed the study and wrote the protocols. Author YD managed the literature searches, performed all experimental work, carried out data and statistical analysis, and wrote the first draft of the manuscript. Both authors read and approved the final manuscript.

Article Information

DOI: 10.9734/JALSI/2017/37185

Editor(s):

Reviewers

Complete Peer review History:

Short Research Article

Received $3^{\text {rd }}$ October 2017

Accepted 24 ${ }^{\text {th }}$ October 2017 Published 28 ${ }^{\text {th }}$ October 2017

\section{ABSTRACT}

Aims: To examine the effects of ascorbic acid (AA), dehydroascorbic acid (DHA) and methotrexate (MTX) combined treatments on (MDA-MB-231) breast cancer cell viability and intracellular reactive oxygen species (ROS).

Study Design: In-vitro method.

Place and Duration of Study: Biomedical Sciences Research Institute, University of Ulster, Coleraine, BT52 1SA, United Kingdom. September 2016-2017

Methodology: Cytotoxicity tests were performed with MTX $(0.01-1000 \mu \mathrm{mol} / \mathrm{l})$ alone or in combination with AA or DHA, for $72 \mathrm{~h}$. Cell viability was measured by 3-4,5 dimethylthiazol-2,5 diphenyl tetrazolium bromide (MTT) or Sulforhodamine B (SRB) assays. Intracellular ROS was measured by 2',7'-dichlorofluroscein diacetate assay.

Results: Treatments of MDA-MB231 cells with single agents, showed dose dependent response with $50 \%$ inhibition of cell viability (IC50) of $110.5-201.4 \mu \mathrm{mol} / \mathrm{l}$ (MTX), $2237-5703 \mu \mathrm{mol} / \mathrm{I}$ (AA) or $2474 \mu \mathrm{mol} / \mathrm{l}(\mathrm{DHA})$. Combination studies showed clear synergisms for MTX ( 10 $\mu \mathrm{mol} / \mathrm{l})$ and DHA or AA $(1100 \mu \mathrm{mol} / \mathrm{l})$ but weak or no interactions at other concentrations. Three days combination treatment of DHA showed decrease of ROS, which was reversed by MTX $(\geq 10 \mu \mathrm{mol} / \mathrm{l})$.

Conclusions: Co-treatment of methotrexate with AA or DHA showed synergism $(\mathrm{C} 1<1.0)$ and 
enhanced cytotoxicity of the anti-folate towards MDA-MB-231 breast cancer cells. Intracellular ROS decreased with $\mathrm{AA}$ and DHA treatment, which might be useful for reducing MTX-related oxidative stress.

Keywords: Ascorbic acid; dehydroascorbic acid; methotrexate; breast cancer; MDA-MB-231 cells; Reactive oxygen species.

\section{INTRODUCTION}

Breast cancer is the most common cancer that affects women worldwide [1]. In the UK, 1 in 8 women may develop breast cancer in their lifetime. In 2014, estimates show that 11,433 people died from breast cancer in the UK alone [2]. Methotrexate (MTX) is an anti-folate drug developed in the late 1940s for the treatment of acute lymphocytic leukemia and other malignancies [3]. MTX cytotoxicity is linked with oxidative stress and increases of intracellular reactive oxygen species (ROS) [4]. MTX therapy also leads to a reduction in the levels of glutathione (GSH) in tissues [5], leading to changes in the redox state, which makes cells more susceptible towards ROS $[4,6,7]$.

Treatment of malignancies with MTX requires a high dose therapy, and is associated with side effects [2], due to the drug not differentiating between normal and cancerous cells [6]. Rapidly dividing cells are particularly susceptible to MTX side-effects [8], resulting in hepatotoxicity, myelosuppression, nephrotoxicity, and intestinal toxicity $[2,9]$.

Supplementation using folic acid or folinic acid are well known strategies for dealing with MTX toxicity [10] but may increase the chances of relapse in patients with leukemia [2]. Antioxidant supplements were found to reduce MTX toxicity linked with high ROS $[5,6,7,8]$. There is longstanding interest in the potential anticancer effects of ascorbic acid (AA), which is a nutrient and a well-known antioxidant [11,12,13,14,15]. Vitamin C had anti-proliferative activity [13], and could enhance effects of doxorubicin, cisplatin and paclitaxel [14], mitoxantrone [15], and methotrexate $[16,17]$. Other studies however, suggested that AA might antagonize antineoplastic drugs leading to reductions in effectiveness [18]. Moreover, AA was noted as a pro-oxidant [19] and in that case is unlikely to reduce drug side effects. Aside from the studies cited above, the use of AA and dehydroascorbic acid (DHA) to reduce MTX toxicity has not been thoroughly studied. The aim of this investigation was to, examine the effects of AA, DHA and MTX combined treatments on MDA-MB-231 breast cancer cell cytotoxicity and intracellular reactive oxygen species (ROS).

\section{MATERIALS AND METHODS}

\subsection{Cell Culture and Plating of Cells}

MDA-MB-231 breast cancer cells (American Type Culture Collection, UK) were cultured in Dulbecco Modified Eagle's Medium (DMEM) (Gibco, UK) supplemented with 10\% FBS (Invitrogen, UK), $1 \%$ Penicillin/Streptomycin (Penn strep) (Invitrogen, UK) and 1\% nonessential amino acid (Invitrogen, UK). Culture flasks and 96 well plates were incubated at $37^{\circ} \mathrm{C}$ in an atmosphere of $5 \%$ CO2 (LEEC Research CO2 Incubator, LEEC Ltd., Nottingham, UK). MDA-MB-231 cells were recovered by trypsinization. The recovered cells were counted using NucleoCounter® (NC-3000, ChemoMetec, Denmark) according to the manufactures instructions. A master mix of cells was prepared to deliver 10,000 cells in a $50 \mu \mathrm{l}$ suspension per well and these dispensed into microplates under sterile conditions (ThermoScientific, UK).

\subsection{Drug Treatment}

A stock solution of MTX (100 mmol/l) dissolved with dimethyl sulfoxide (DMSO) was diluted 10fold with DMEM and filter sterilized using $0.2 \mu \mathrm{m}$ filters (Millex-HA sterile filter units; Merck Millipore Ltd, Co. Cork Ireland). The MTX solution in DMEM media was serially diluted at concentrations $0.01,0.1,1,10,100,1000 \mu \mathrm{mol} / \mathrm{l}$ using DMEM. AA or DHA was first dissolved in DMEM media (2 - $20 \mathrm{mmol} / \mathrm{l}$ ) and filter sterilized using $0.2 \mu \mathrm{m}$ filters and serially diluted at concentration $0.1,1,10,100,1000,10000$ $\mu \mathrm{mol} / \mathrm{l})$. Sterile solutions of drugs to be tested (50 $\mu \mathrm{l})$ were added to cells at the $2 x$-concentrations mentioned and incubated for $72 \mathrm{~h}$ at $37^{\circ} \mathrm{C}$. Cell viability was measured using MTT or sulforhodamine $B($ SRB) assays [20,21].

\subsection{Combination Drugs Study}

The 50\% inhibitor concentration for each agent (IC50) was determined and one half of the IC50 
of $A A$ and $D H A$ found to be approximately 1100 $\mu \mathrm{mol} / \mathrm{l}$ (see below). Therefore, AA or DHA (1100 $\mu \mathrm{mol} / \mathrm{l})$ was used for combination with varying concentration of MTX. Cells were treated with MTX $(0.1,1.0,10,100,1000 \mu \mathrm{mol} / \mathrm{l}$ final concentrations) and a fixed concentration of $A A$ or DHA at $1100 \mu \mathrm{mol} / \mathrm{l}$ for 72 hours and MTT and SRB assays. Cell viability results were analysed by CompuSyn ${ }^{\mathrm{TM}}$ software $[22,23]$ to determine, the IC50 alongside of the combination index $(\mathrm{Cl})$, where $\mathrm{Cl}<1, \mathrm{Cl}=1$ or $\mathrm{Cl}>1$ shows, synergism, additive responses or antagonism, respectively. A combination study of DHA and MTX was also performed for the determination of reactive oxygen species (ROS) using 2', 7'dichlorofluorescein diacetate (DCFH-DA) assay.

\subsection{MTT Assay and Sulforhodamine B Assays for Cell Viability}

The MTT assay was performed as described before [20] with modification. MTT (5mg per 100 $\mathrm{ml}$ PBS) was filter sterilized $(0.2 \mu \mathrm{M}$ filter) before use. Cells were washed three times with cold PBS $(50 \mu \mathrm{l} \times 3)$ leaving behind $50 \mu \mathrm{L}$ of PBS in each well. MTT solution $(20 \mu \mathrm{l})$ was added to each well and microplates were incubated at $37^{\circ} \mathrm{C}$ for $2 \mathrm{~h}$. Formazan crystals formed were dissolved by treating with $100 \mu \mathrm{l}$ acidified isopropanol (with $0.04 \mathrm{M} \mathrm{HCL}$ ) for $1 \mathrm{~h}$. Absorbance was read at $570 \mathrm{~nm}$ using a microplate reader (VERSA Max Micro plate reader; Molecular Devices, USA).

Sulforhodamine B (SRB) staining was carried out according to the method described in [21] with a few modifications. Cells were fixed with $100 \mu \mathrm{l}$ of cold trichloroacetic acid (TCA $10 \% \mathrm{w} / \mathrm{v}$ ) and incubated at $5^{\circ} \mathrm{C}$ for 30 minutes. Cells were washed four times with tap water, blot dried after each wash, and then stained with $100 \mu \mathrm{l}$ of SRB dye $(0.06 \%$ solution in $1 \%$ acetic acid) (SigmaAldrich, UK) at room temperature for 30 minutes. Plates were de-stained by washing with $1 \%$ acetic $(100 \mu \mathrm{l} \times 3)$ acid and allowed to air dry. Trizma-base solution $(10 \mathrm{mmol} / \mathrm{l})$ was added to each well $(200 \mu \mathrm{l})$ and placed on a shaker for 5 min. Absorbance was read at $564 \mathrm{~nm}$ on a microplate reader.

\subsection{DCFH-DA Assay}

Intracellular ROS was determined using DCFHDA assay [24]. DCFH- DA stock solution (20.5 $\mathrm{mmol} / \mathrm{l}$ ) was made by adding $10 \mathrm{mg}$ of DCFH-DA with $1 \mathrm{ml}$ of DMSO $(1 \mathrm{ml})$. To make DCFH-DA working solution, $10 \mathrm{ml}$ of hank salt solution was added to $25 \mu \mathrm{l}$ of DCFH-DA stock solution in a universal container and was filter sterilised. Cells were plated to deliver 10,000 cells/well in 96 well black polystyrene plates with $50 \mu \mathrm{L}$ media per well and incubated overnight at $37^{\circ} \mathrm{C}$ to allow for the adherence of cells.

For the 60 min study cells were washed once with cold $200 \mu \mathrm{l}$ of hank salt solution, which was then pipetted out. DCFH-DA working solution (50 $\mu \mathrm{l}$ ) was added to cells and incubated for $45 \mathrm{~min}$ at $37^{\circ} \mathrm{C}$. Cells were then rinsed once with $200 \mu \mathrm{l}$ of culture media DMEM, Drug treatment was performed by treating cells with AA or DHA as described above (Section 2.2.) with media as control and incubated for $60 \mathrm{~min}$ at $37^{\circ} \mathrm{C}$. Fluorescence was read at $485 \mathrm{~nm}$ excitation and $520 \mathrm{~nm}$ emission wavelengths on a microplate reader (FLUOstar Omega, BMG Labtech, Germany). A 72-h treatment study with DHA and MTX was performed as described above except drug treatment was for $72 \mathrm{~h}$. Experiments were performed on at least two separate occasions with each drug treatment concentration repeated at least 12-24 times.

\subsection{Statistical Analysis}

One-way ANOVA tests were performed using SPSS software version 23 to identify significant differences between the means of treatments groups, statistical significant differences were considered to be $P$ value $<0.05$. Results are expressed as mean \pm standard error.

\section{RESULTS}

\subsection{Single Drug Tests, MTT Assay for MDA-MB-231 Breast Cancer}

Single drug tests were performed using MTX, AA and DHA on MDA-MB-231 breast cancer cells for $72 \mathrm{~h}$ and then cell viability was assessed by the MTT assay (Fig. 1). There was dose-dependent decrease in cell viability. By contrast, $A A$ and DHA were found to be non-cytotoxic at the concentrations examined (Fig. 1). The concentrations of each agent giving $50 \%$ inhibition of cell viability (IC50) were estimated from CompuSyn ${ }^{\mathrm{TM}}$ software and are shown in Table 1 (MTT assay). When using the MTT assay, there was no cytotoxicity effect for DHA even at concentrations of $10 \mathrm{mmol} / \mathrm{l}$ (data not shown). 
Table 1. Dose-response parameters determined by CompuSyn ${ }^{\mathrm{TM}}$ for MTT Assay

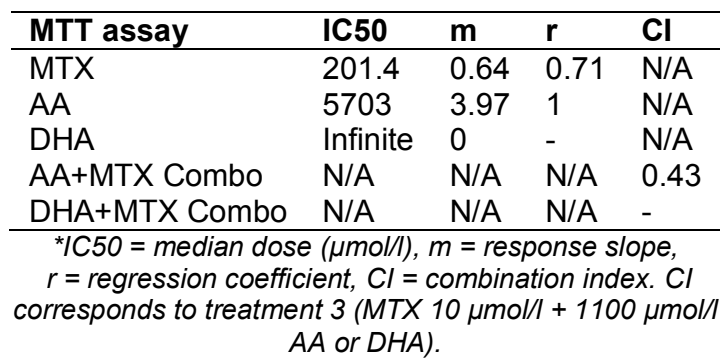

\subsection{Single Drug Tests, Sulforhodamine Assay for MDA-MB-231 Breast}

Single drug tests were performed using MTX, AA and DHA on MDA-MB-231 breast cancer cells for $72 \mathrm{~h}$ and with cell viability assessed by the sulforhodamine assay (Fig. 2). For MTX, a significant decrease in cell viability of $39 \%$ and $54 \%$ were seen for treatment 4 and 5, respectively compared to the control (treatment 1). The highest concentrations of $A A$ and $D H A$ tested produced a decrease in cell viability of $14 \%$ for AA and $16 \%$ for DHA. Table 2 shows the IC50 values for MTX, AA and DHA respectively.

\subsection{Combination Treatment of MDA-MB- 231 Cells with MTX and AA or DHA}

The combination index $(\mathrm{Cl})$ determined by CompuSyn ranged from 0.43- 251 when cells viability was assayed using MTT assay while, $\mathrm{Cl}$ range 0.46-0.91 with the SRB assay (Table 2). The $\mathrm{Cl}$ values correspond to treatments with 10 $\mu \mathrm{mol} / / \mathrm{l}$ of MTX $+1100 \mu \mathrm{mol} / \mathrm{l} \mathrm{AA}$ (as seen in Fig. 1 \& Fig. 2, treatment 3). For the MTX and DHA combination treatment monitored with the MTT assay no toxicity effect was seen in DHA, as a result no $\mathrm{Cl}$ value could be calculated. $\mathrm{A} \mathrm{Cl}$ value of 0.91 was obtained for MTX and DHA combination treatment for SRB assay (Table 2), which is the middle dose treatment that contains $10 \mu \mathrm{mol} / /$ of $\mathrm{MTX}+1100 \mu \mathrm{mol} / / \mathrm{DHA}$ showing synergism (also seen in Fig. 2, treatment 3).

\subsection{CompuSyn Predictions for $\mathrm{Cl}$ over Wider Concentration Ranges}

For all combination studies, CompuSyn analysis predicted large values for $\mathrm{Cl}$ when at low concentrations of MTX (e.g. C1 $=0.41-5000$ and $\mathrm{Cl}=0.91)$. The significance of such large predicted $\mathrm{Cl}$ value is not certain.
Table 2. Dose-response parameters determined by CompuSyn ${ }^{\mathrm{TM}}$ for SRB assay

\begin{tabular}{lllll}
\hline SRB assay & IC50 & $\mathbf{m}$ & $\mathbf{r}$ & $\mathbf{C l}$ \\
\hline MTX & 110.5 & 0.89 & 0.88 & N/A \\
AA & 2237 & 0.86 & 0.91 & N/A \\
DHA & 2474 & 0.70 & 0.96 & N/A \\
AA+MTX Combo & N/A & N/A & N/A & 0.46 \\
DHA+MTX Combo & N/A & N/A & N/A & 0.91 \\
\hline *IC50 = median dose $(\mu m o / / I)$, & $m=$ response slope, $r=$ \\
regression coefficient, CI $=$ combination index. Cl \\
corresponds to treatment 3 $(M T X 10 \mu m o l / l+1100 \mu m o l / I$ \\
AA or DHA).
\end{tabular}

\subsection{Drug Effects on Intracellular ROS in MDA-MB-231 Cells}

One-hour treatment with $1-1000 \mu \mathrm{mol} / \mathrm{l}$ of $\mathrm{AA}$ or DHA produced small changes $(+/-10 \%)$ changes in intracellular ROS with no consistent pattern (data not shown). By comparison treatment with DHA for 72 hours produced a $50 \%$ decrease of ROS compared with media only control (Fig. 3). For comparison, treatment with MTX $(0.1-1000$ $\mu \mathrm{M})$ plus a fixed $D H A(1100 \mu \mathrm{mol} / \mathrm{l})$ showed no apparent tendency to increase the ROS above the value for the control. Assuming that the ROS changes derive only from viable cells, the preceding results were also adjusted to take account of percentage changes in cell viability (Fig. 3). The intracellular ROS data for viable cells showed that MTX co-treatments at $>10$ $\mu \mathrm{mol} / /$ produced rising levels of oxidative stress (Fig. 3, Shaded bars).

\section{DISCUSSION}

Therapeutic use of MTX for breast cancer treatment could be improved if the toxic side effects due to ROS were eradicated. Many studies have reported using various antioxidants to decrease MTX toxicity by lowering ROS $[5,7,8$, $25,26,27]$. Other studies reported the anti-cancer ability of AA, with concentration of $0.25-1 \mathrm{mmol} / \mathrm{l}$ being able to cause toxicity in cancer cells [11, 12,28-30.] However, AA at lower concentration was shown to act as a protector for cells. which might explain some of the conflicting results reported $[14,26]$. AA was also reported to be more toxic to cancer cells compared with normal cells, though the reasons behind this selectivity is not clear [28-30]. Studies have shown AA can lower the side effects caused by neoplastic drugs by enhancing their cytotoxicity, resulting in lower dosage of these drugs being used for cancer treatment [14-17]. 

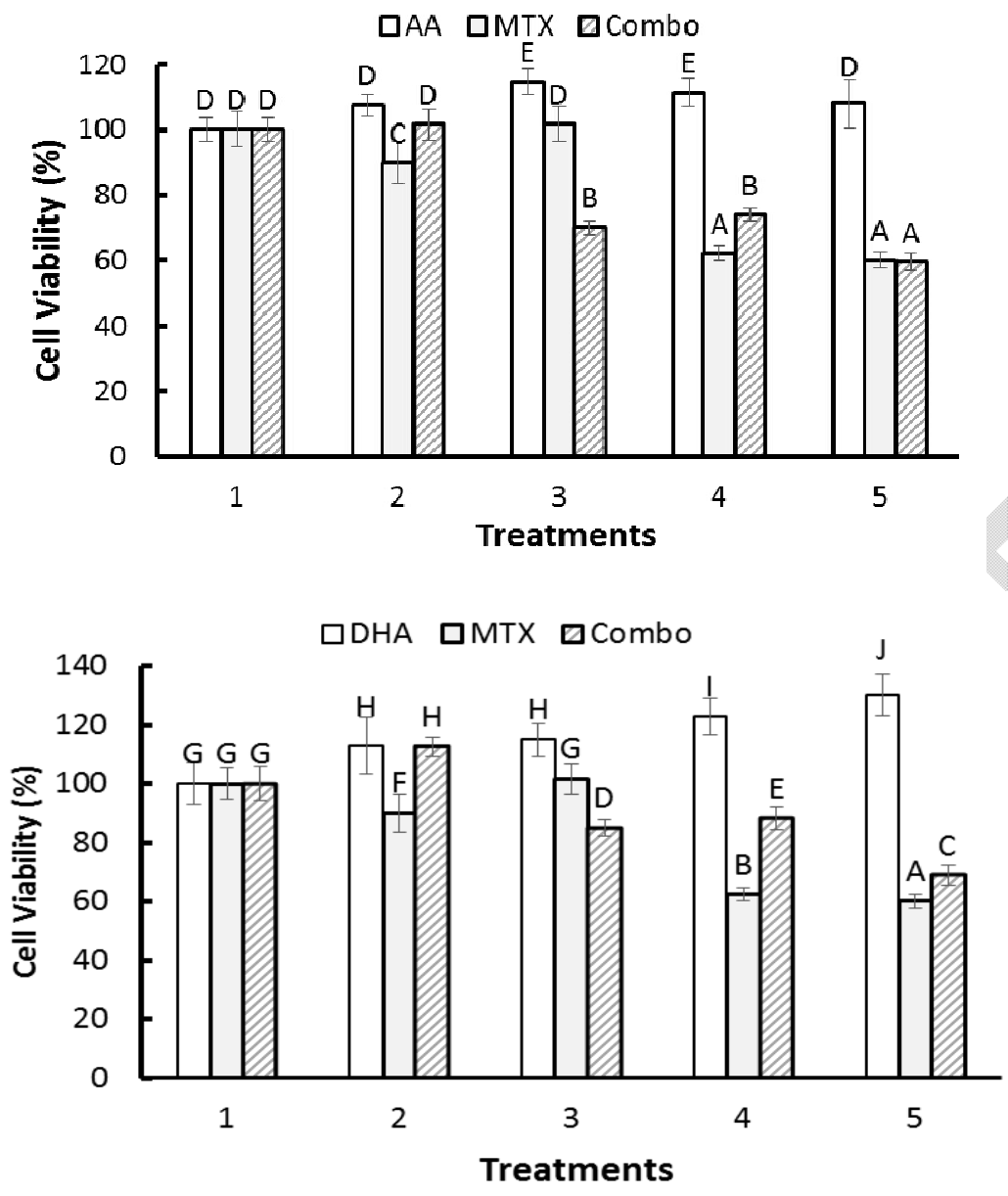

Fig. 1. Effect of methotrexate (MTX) treatment with MDA-MB-231 cells in combination with Ascorbic acid (AA; Top) or dehydroascorbic acid (DHA; lower panel) with cell viability determined by MTT assay.

The $x$-axis shows treatments (1-5) with AA (0.1, 1.0, 10, 100, $1000 \mu \mathrm{mol} / \mathrm{I}), \operatorname{MTX}(0.01,0.1 .1 .0,10,100 \mu \mathrm{mol} / \mathrm{I})$, and combinations $(0.1,1.0 .10,100,1000 \mu \mathrm{mol} / \mathrm{I} M T X)+1100 \mu \mathrm{mol} / \mathrm{l}$ AA or DHA. Bars with different letters $(A-E)$ show significant differences ( $p$ value $<0.05$ ). Results are expressed as mean \pm standard error. Experiment were repeated on two different occasions $n=12-24$ of pooled data. Final DMSO concentration $=0 \%, 0.001 \%, 0.01 \%$,

$0.1 \%$ and $1 \%$ for treatments $1-5$.

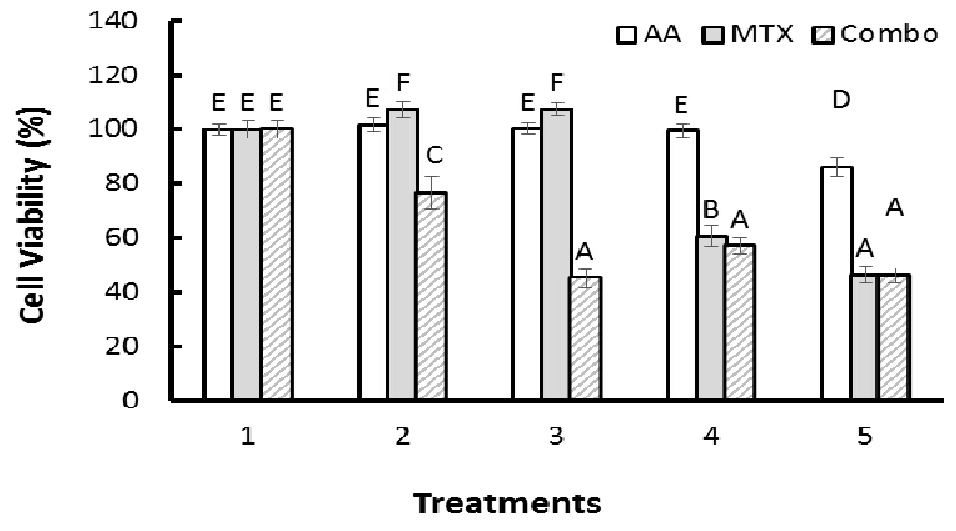




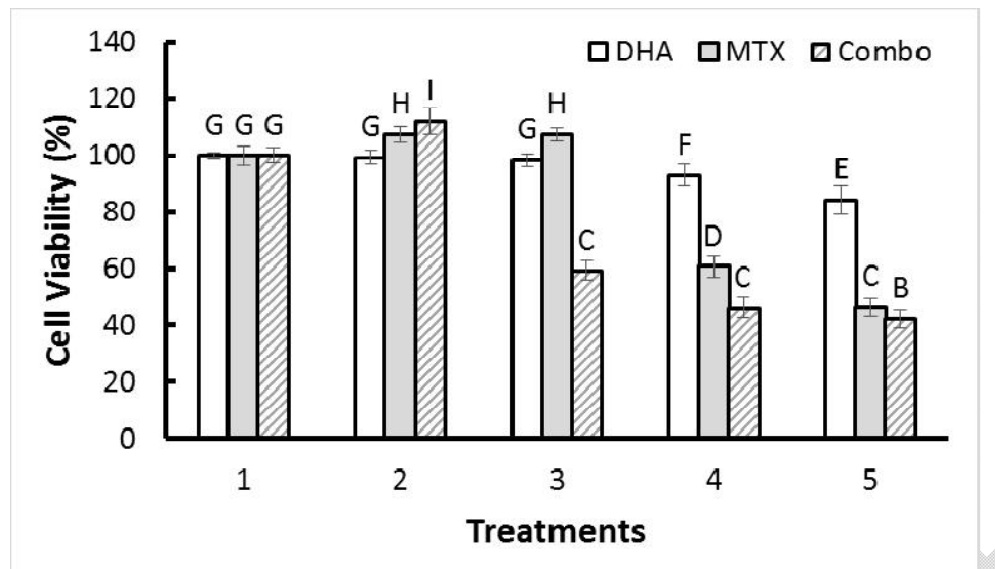

Fig. 2. Effect of methotrexate (MTX) treatment with MDA-MB-231 cells in combination with Ascorbic acid (AA; Top) or dehydroascorbic acid (DHA; lower panel) with cell viability determined by sulforhodamine $B$ assay.

The $x$-axis shows treatments (1-5) with $A A(0.1,1.0,10,100,1000 \mu \mathrm{mol} / \mathrm{I}), \mathrm{MTX}(0.01,0.1 .1 .0,10,100 \mu \mathrm{mol} / \mathrm{I})$, and combinations $(0.1,1.0 .10,100,1000 \mu \mathrm{mol} / \mathrm{I} \mathrm{MTX})+1100 \mu \mathrm{mol} / \mathrm{I} A A$ or DHA in all cases. Bars with different letters $(A-E)$ show statistical significant differences $(p$ value $<0.05)$. Results are expressed as mean \pm standard error. Experiment were repeated on two different occasions $n=12-24$ of pooled data. Final DMSO concentration $=0 \%, 0.001 \%, 0.01 \%, 0.1 \%$ and $1 \%$ for treatments $1-5$.

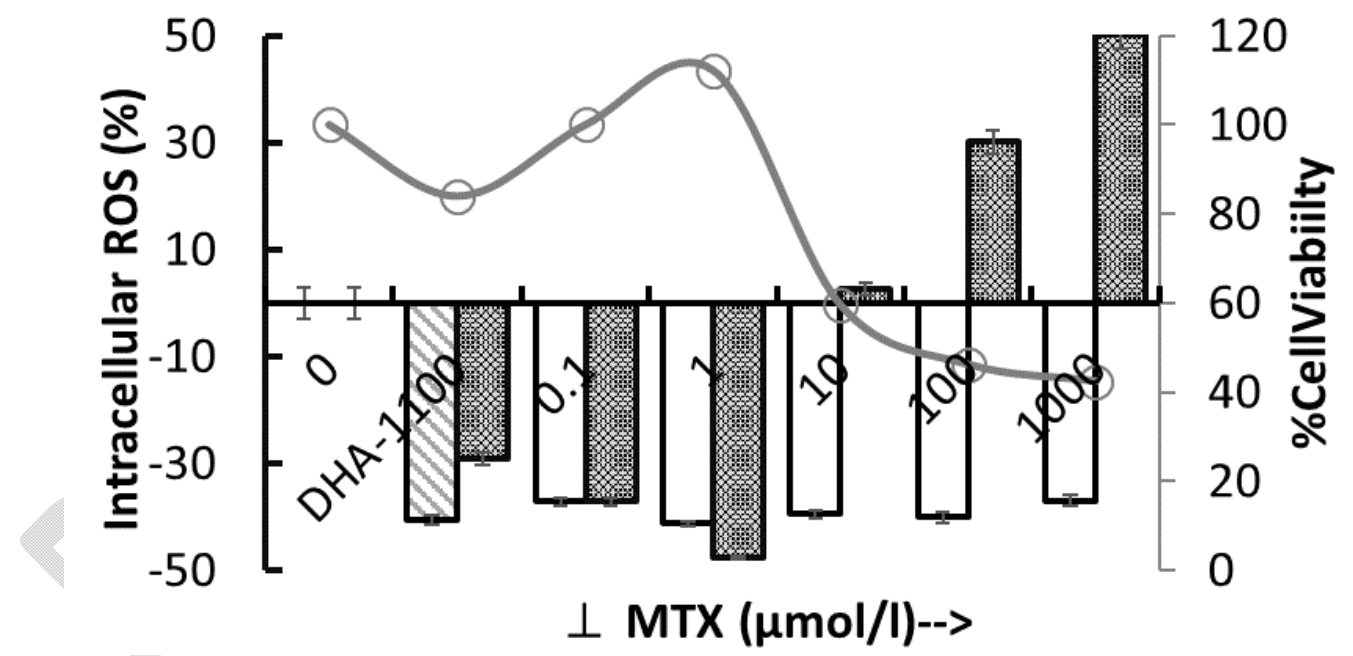

Fig. 3. Effect of dehydroascorbic acid (DHA) and methotrexate (MTX) combination treatments on MDA-MB-231 intracellular ROS cells

Cells were treated with $\operatorname{MTX}(0.1,1.0 .10,100,1000 \mu \mathrm{mol} / \mathrm{I})+\mathrm{DHA}$ at a fixed concentration of $1100 \mu \mathrm{mol} / \mathrm{l}$. Negative control = cell treated with no drug (0), Positive control = cell treated with DHA (1100 $\mu$ mol/I). ROS data

shows mean \pm standard error (left axis). \% Cell Viability (right axis) is continuous line. Shaded bars $=$ ROS adjusted for viable cells. Experiments were repeated on two different occasions $n=12-24$ of pooled data. Final DMSO concentration $=0.001 \%, 0.01 \%, 0.1 \%$ and $1 \%$ for MTX treatments $0.1-1000 \mu \mathrm{mol} / \mathrm{l}$.

In this study, the cytotoxicity of MTX, AA and DHA were tested for each compound using MDA-MB-231 cells. The cytotoxicity of MTX was demonstrated but IC50 values that were found that proved to be higher than that of the only study (to our knowledge) that performed the analyses under very similar conditions. Kelly \& Owusu-Apenten found the IC50 of MTX was 35 
$\mu \mathrm{mol} / \mathrm{l}$ after $72 \mathrm{~h}$ of treatment using the MTT assay in MDA-MB-231 cells, which is significantly lower than the IC50 of $201.4 \mu \mathrm{mol} / \mathrm{l}$ obtained in this study [31]. Other studies that reported the IC50 of MTX used drug treatments at a shorter time or/and with different cell lines. The IC50 for both AA and DHA were found to be similar using the SRB assay. To our knowledge, no previous study reported an IC50 for AA and DHA in MDAMB-231 cells. Frömberg et al. reported the IC50 of $A A$ and DHA in other cells lines, as 1.7 to $>60$ mM (AA) or 12.7- $14.9 \mathrm{mM}$ (DHA) and concluded that $A A$ demonstrated a higher therapeutic effect over DHA in the cell lines [13].

Investigating both $\mathrm{AA}$ and $\mathrm{DHA}$ combination with MTX was intended to shed light on the effect of two different $A A$ forms. $A A$ is an antioxidant and nutrient supplement. DHA is the oxidised form of AA and has antioxidant capacity [18]. Although the level of $A A$ found in the human serum is relatively high, intracellular transportation is thought to limited to only a few tissues. In contrast, DHA enters cells readily by the glucose transporter (GLUT1). Intracellular DHA becomes reduced and accumulates in the cell, leading to increased levels of intracellular AA. High concentrations of AA in cells works with endogenous $\mathrm{GSH}$ to reduce the effects of ROS [18]. Past research showed that AA may behave as a pro-oxidant at higher concentration by producing ROS, which is a possible reason for its anti-cancer ability $[12,19]$. It is noteworthy that for normal tissue, AA is taken up by sodiumdependent vitamin C transporters (SVCT) [32]. The similar cell viability responses observed with AA and DHA (Fig. 1 \&2) suggests that AA was oxidized extracellularly to DHA before uptake, as was demonstrated for leukaemia (K562) and lymphoma (RL) cells [18] and other cell lines [33]. However, the distribution of SVCT in breast cancer cell lines can neither be confirmed nor dismissed at present; therefor it is not certain whether efficient uptake of vitamin $C$ by MDAMB-231 cells is or is not possible.

According to current results, there were synergistic interactions between AA and MTX and also DHA and MTX. The synergistic effects were observed whether cytotoxicity was monitored by the MTT assay or SRB assay. To our knowledge, this is the first study to analyse the cytotoxicity of MTX, AA and DHA using both MTT and SRB assays. IC50 values obtained using the MTT assay were approximately double the IC50 values obtained for the SRB assay. The assays measure different indices for cells viability. The MTT assay measures mitochondrial activity while SRB assay measures cell protein. The former assay is influenced by acidic $\mathrm{pH}$ and reducing agents such as $\mathrm{AA}[20]$.

Synergism was most apparent at treatment concentrations "straddling" the IC50 value for MTX (treatments 3-4, Figs. 1 \& 2). These findings agree with past reports $[14,15,16]$. Kurbacher et al reported that low levels (1 $\mu$ mole/l) of AA had a synergistic or additive response in combination with other neoplastic drugs in MDA-MB-231 and MCF-7 cells [14]. The concentrations of AA used were lower in comparison to the doses in this study. A recent study by Wu et al also reported a synergistic effect of non-toxic doses of AA combined with MTX and attributed such effects to increases of intracellular hydrogen peroxide and activation of apoptosis pathways [17]. Analysis of interactions based on values for $\mathrm{Cl}$ requires a knowledge of the toxic doses for both agents under investigation and for this reason we examined $\mathrm{AA}$ and DHA over a wide concentration range.

Intracellular ROS levels were largely unchanged $(+/-10 \%$ control values) after an hour treatment with $A A$ or DHA in MDA-MB-231 cells. By comparison, $72 \mathrm{hr}$ treatment with DHA showed $50 \%$ reduction in intracellular ROS, and the reduction was retained after addition of MTX (0.1-1000 $\mu \mathrm{M})$. However, others reported that low concentrations of AA could increase ROS when combined with low doses of MTX in MDAMB-231 cells [17]. When in Fig 3, the intracellular ROS values are adjusted for viable cells it became evident that MTX increases oxidative stress at concentrations of $>10 \mu \mathrm{M}$. Past research suggests that drug-induced ROS arise from a variety of processes affecting mitochondrial morphology and function $[27,35]$, drug biotransformations, or autoxidation. Moreover, DCFH-DA intracellular probe shows mitochondrial and cytoplasmic changes to ROS [34]. Interestingly, recent research using astrocytes showed that ROS increases could arise from exposure to $1-5 \%$ DMSO due to changes of mitochondrial integrity [35].

\section{CONCLUSION}

Ascorbic acid and DHA were found to be cytotoxic towards MDA-MB-231 cells. Combination treatment of AA or DHA with MTX resulted in synergistic responses indicating improved effectiveness of the anti-folate drug. Analysis of intracellular ROS showed that AA or 
DHA co-treatment could maintain low levels of oxidative stress. Further research is required to study different combinations of AA and MTX for treatment of breast cancer.

\section{COMPETING INTERESTS}

Authors have declared that no competing interests exist.

\section{REFERENCES}

1. Shah $\mathrm{R}$, Rosso $\mathrm{K}$, Nathanson SD. Pathogenesis, prevention, diagnosis and treatment of breast cancer. World J Clin Oncol. 2014;5(3):283.

2. Cancer Research UK. Breast cancer statistics; 2014.

Available:http://www.cancerresearchuk.org /health-professional/cancer-

statistics/statistics-by-cancer-type/breastcancer\#heading-Zero (Accessed: 24th May 2017)

3. Schmiegelow K. Advances in individual prediction of methotrexate toxicity: A review. Br J Haematol. 2009;146(5):489_ 503.

4. Coleshowers CL, Oguntibeju OO, Ukpong M, Truter EJ. Effects of methotrexate on antioxidant enzyme status in a rodent model. Med Technol SA. 2010;24(1):5-9.

5. Jahovic N, Cevik H, Sehirli AO, Yeğen BC, Sener G. Melatonin prevents methotrexate-induced hepatorenal oxidative injury in rats. $\mathrm{J}$ Pineal Res. 2003;34(4):282-7.

6. Vardi N, Parlakpinar H, Ozturk F, Ates B, Gul M, Cetin A, et al. Potent protective effect of apricot and $\beta$-carotene on methotrexate-induced intestinal oxidative damage in rats. Food Chem Toxicol. 2008;46(9):3015-22.

7. Tabassum H, Parvez S, Pasha ST, Banerjee BD, Raisuddin S. Protective effect of lipoic acid against methotrexateinduced oxidative stress in liver mitochondria. Food Chem Toxicol. 2010;48(7):1973-1979.

8. Dadhania VP, Tripathi DN, Vikram A, Ramarao $P$, Jena GB. Intervention of $\alpha$ lipoic acid ameliorates methotrexateinduced oxidative stress and genotoxicity: A study in rat intestine. Chem Biol Interact. 2010;183(1):85-97.

9. Miyazono Y, Gao F, Horie T, Horie T. Oxidative stress contributes to methotrexate-induced small intestinal toxicity in rats. Scand J Gastroenterol. 2004;39(11):1119-27.

10. Padmanabhan S, Tripathi DN, Vikram A, Ramarao $P$, Jena GB. Methotrexateinduced cytotoxicity and genotoxicity in germ cells of mice: Intervention of folic and folinic acid. Mutat Res - Genet Toxicol Environ Mutagen. 2009;673(1):43-52.

11. Unlu A, Kirca O, Ozdogan M, Nayır E. High-dose vitamin $\mathrm{C}$ and cancer. J Oncol Sci. 2016;1:10-2.

12. Verrax J, Buc Calderon $P$. The controversial place of vitamin $C$ in cancer treatment. Biochem Pharmacol. 2008; 76(12):1644-52.

13. Frömberg A, Gutsch D, Schulze D, Vollbracht C, Weiss G, Czubayko F, et al. Ascorbate exerts anti-proliferative effects through cell cycle inhibition and sensitizes tumor cells towards cytostatic drugs. Cancer Chemother Pharmacol. 2011; 67(5):1157-66.

14. Kurbacher CM, Wagner $U$, Kolster B, Andreotti PE, Krebs D, Bruckner HW. Ascorbic acid (vitamin C) improves the antineoplastic activity of doxorubicin, cisplatin, and paclitaxel in human breast carcinoma cells in vitro. Cancer Lett. 1996;103(2):183-9.

15. Guerriero E, Sorice A, Capone F, Napolitano V, Colonna G, Storti G, et al. Vitamin $C$ effect on mitoxantrone-induced cytotoxicity in human breast cancer cell lines. PLoS One. 2014;9(12):1-15.

16. Yiang GT, Chou PL, Hung YT, Chen JN, Chang WJ, Yu YL, et al. Vitamin C enhances anticancer activity in methotrexate-treated Hep3B hepatocellular carcinoma cells. Oncol Rep. 2014;32(3): 1057-63.

17. Wu CW, Liu HC, Yu YL, Hung YT, WeiWei C, Yiang GT. Combined treatment with vitamin $\mathrm{C}$ and methotrexate inhibits triple-negative breast cancer cell growth by increasing $\mathrm{H} 2 \mathrm{O} 2$ accumulation and activating caspase-3 and p38 pathways. Oncol Rep 2. 2017;37:2177-2184.

18. Heaney ML, Gardner JR, Karasavvas N, Golde DW, Scheinberg DA, Smith EA, et al. Vitamin $C$ antagonizes the cytotoxic effects of antineoplastic drugs. Cancer Res. 2008;68(19):8031-8.

19. Rietjens IMCM, Boersma MG, Haan $L$ de, Spenkelink B, Awad HM, Cnubben NHP, et al. The pro-oxidant chemistry of the natural antioxidants vitamin $\mathrm{C}$, vitamin $\mathrm{E}$, 
carotenoids and flavonoids. Environ Toxicol Pharmacol. 2002;11(3-4):321-33.

20. Twentyman PR, Luscombe M. A study of some variables in a tetrazolium dye (MTT) based assay for cell growth and chemosensitivity. $\mathrm{Br} \mathrm{J}$ Cancer. 1987; 56(3):279.

21. Vichai V, Kirtikara K. Sulforhodamine B colorimetric assay for cytotoxicity screening. Nature Protocols. 2006;1(3): 1112-1116.

22. Chou TC, Martin N. CompuSyn for drug combinations and for general dose-effect analysis. 2015. Accessed 17th Oct 2016. Available:http://www.combosyn.com/featur e.html

23. Breitinger HG. Drug synergy-mechanisms and methods of analysis. In William A, editor. Toxicity and drug Testing. INTECH; 2012.

DOI: $10.5772 / 30922$

24. Wang $\mathrm{H}$, Joseph JA. Quantifying cellular oxidative stress by dichlorofluorescein assay using microplate reader. Free Radical Biology and Medicine. 1999;27(5):612-6.

25. Mukherjee S, Ghosh S, Choudhury S, Adhikary A, Manna K, Dey S, et al. Pomegranate reverses methotrexateinduced oxidative stress and apoptosis in hepatocytes by modulating Nrf2-NF-KBB pathways. J Nutr Biochem. 2013;24(12): 2040-50.

26. Ali N, Rashid S, Nafees S, Hasan SK, Shahid A, Majed F, et al. Protective effect of Chlorogenic acid against methotrexate induced oxidative stress inflammation and apoptosis in rat liver: An experimental approach. Chem Biol Interact. 2017;272: 80-91.

27. Paul M, Hemshekhar M, Thushara RM, Sundaram MS, NaveenKumar SK, Naveen $\mathrm{S}$, et al. Methotrexate promotes platelet apoptosis via JNK-mediated mitochondrial damage: Alleviation by $\mathrm{N}$-acetylcysteine and $\mathrm{N}$-acetylcysteine amide. PloS One. 2015;10(6):e0127558.

28. Park S. The effects of high concentrations of vitamin $\mathrm{C}$ on cancer cells. Nutrients. 2013;5(9):3496-505.

29. Vuyyuri SB, Rinkinen J, Worden E, Shim $H$, Lee S, Davis KR. Ascorbic acid and a cytostatic inhibitor of glycolysis synergistically induce apoptosis in nonsmall cell lung cancer cells. PLoS One. 2013;8(6).

30. Chen Q, Espey MG, Krishna MC, Mitchell $\mathrm{JB}$, Corpe CP, Buettner GR, et al. Pharmacologic ascorbic acid concentrations selectively kill cancer cells: action as a pro-drug to deliver hydrogen peroxide to tissues. Proc Natl Acad Sci U S A. 2005;102(38):13604-9.

31. Kelly T, Owusu-Apenten R. Effect of Methotrexate and Tea Polyphenols on the Viability and Oxidative Stress in MDA-MB231 Breast Cancer Cells. J Appl Life Sci Int. 2015;2(4):152-9.

32. Corti A, Casini AF, Pompella A. Cellular pathways for transport and efflux of ascorbate and dehydroascorbate. Arch Biochem Biophys. 2010;500(2):107-15.

33. Agus DB, Vera JC, Golde DW (1999). Stromal cell oxidation: A mechanism by which tumors obtain vitamin C. Cancer Res. 1999;59(18):4555-4558.

34. Pereira CV, Nadanaciva S, Oliveira PJ, Will $Y$. The contribution of oxidative stress to drug-induced organ toxicity and its detection in vitro and in vivo. Expert Opin Drug Metab Toxicol. 2012;8(2):219-37.

35. Yuan C, Gao J, Guo J, Bai L, Marshall C, Cai Z, Wang L, Xiao M. Dimethyl sulfoxide damages mitochondrial integrity and membrane potential in cultured astrocytes. PloS One. 2014;9(9):e107447.

(c) 2017 Dosunmu and Owusu-Apenten; This is an Open Access article distributed under the terms of the Creative Commons Attribution License (http://creativecommons.org/licenses/by/4.0), which permits unrestricted use, distribution, and reproduction in any medium, provided the original work is properly cited.

Peer-review history:

The peer review history for this paper can be accessed here: http://sciencedomain.org/review-history/10035 